Ramazan Akdoğan ${ }^{1}$

\section{A Holistic Approach to Cope with Depression and Hopelessness for Parents of Special Needs Children}

\begin{abstract}
This study aims to identify psychological difficulties the parents $(n=24)$ of children with various handicaps from their opinions through a holistic perspective; and reveal the effectiveness of group counseling based on eclectic approach to cope with these difficulties. Study was conducted in two successive steps. During the first step, the data related to the experiences of parents based on having a handicapped child were collected through a structured interview form. As for the second step, a group counseling program which formed within the light of qualitative data gathered in first step was applied, and the effect of the program on depression and hopelessness levels of parents was examined through an experimental design of $2 \times 2$. Findings of the study showed that the program had a significant effect on decreasing depression and hopelessness levels of the parents.

Keywords:

Parents of handicapped children, depression, hopelessness, eclectic approach
\end{abstract}

\section{Introduction}

Being someone with special needs is a condition with personal and interpersonal consequences. It is personal as being with special needs causes the individual to be different from his or her peers with normal developmental characteristics (Cavkaytar, 2013); not to participate in life in a functional and sufficient way due to this difference (Eripek, 2005); or even if s/he wants to participate in, his/her being excluded from society and being exposed to discrimination (Akbulut, 2012) which result with challenges that make the life of individual difficult. On the other hand, being with special needs is a condition which has interpersonal effects and consequences. Thus, the individual with disability is affected by the social and familial environment s/he is in on one hand; and affects the other family members and social environments on the other (Reichman, Corman \& Noonan, 2008). In other words, being with special needs is not only a problem for the individual him or herself, but also it is a situation that directly or indirectly affects mainly his or her parents, siblings and relatives, and friends and teachers (DePauw, 2000; Wagner, Borduin, Kanne, Mazurek, Farmer \& Brown, 2014). For this reason, special education can be considered as an interdisciplinary field that is expected to focus on both individuals with special needs and the problems of the family members of these individuals.

Family has been the subject of various studies as it affects the individual with special needs primarily, and is affected by this situation. As a factor that affects the condition of a child with special needs, "family education" is a frequently used term referring to the involvement of parents to the education process and the ways they can support their children in the literature of special education (Ardıç, 2010; Cavkaytar, 1998; Cavkaytar, Ardıç, Sönmez, Özdemir \& Olcay, 2013; Fish, 2008; Uygur, Özen, Baş, Gönül \& Songur, 2013; Spann, Kohler \& Soenksen, 2003). Although some studies focused on psychosocial process the family was in (Ardıç, 2013), most of the studies focused on involving participation of family in education process of the child with special needs in an effective way.

\footnotetext{
1 Ph.D., Anadolu University, Faculty of Education, Department of Educational Sciences, Program in Guidance and Psychological Counseling, Eskişehir TURKEY.

e-mail: rakdogan@anadolu.edu.tr
} 
Various studies have been conducted on psychological experiences of parents as they are a focus group primarily affected by the child with disabilities. In this framework, various psychological variables such as self-efficacy perceptions (Al-Kandari \& Al-Qashan, 2010; Hastings \& Brown, 2002), successful parenting skills (Algood \& Harris, 2013), family functions (Özşenol, Işıkhan, Ünay, Aydın, Akın \& Gökçay, 2003), life satisfactions (Akandere, Acar \& Başbuğ, 2009), social support perceptions (Coşkun \& Akkaş, 2009), constant stress (Glenn, Cunningham, Poole, Reeves \& Weindling 2008) and life styles (Witcher, 1987) have been the subjects of these studies.

Research has revealed that parents experienced various problems related to each other based on having a child with special needs. Some of these problems which were related to the education process of the child (Shanker, 1995), health needs (Maatta, Maatta, Tervo-Maatta, Taanila, Kaski \& Livanainen, 2011; Spender, Stein, Dennis, Reilly, Percy \& Cave' 2008; Uygur \& diğ.,2013), and social prejudices (Ayyıldız, Şener, Kulakçı \& Veren, 2012; Beckett, 2009; Zibricky, 2014) have been observed to threaten psychological heath of parents in the long term. Continuity of these problems brings depression and hopelessness as a part of their lives for the parents with children with disabilities. Thus, various studies conducted on parents with handicapped children revealed that the difficulty of dealing with their children caused them experience depression (Bahar, Bahar, Savaş \& Parlar, 2009; Bitsika \& Sharpley, 2004; Blacher, Lopez, Shapiro \& Fusco, 2016; Ceylan \& Aral, 2007a; Foster, Garber \& Durlak, 2008; Karadağ, 2009) and hpelessness (Ceylan \& Aral, 2007b; Ergüner-Tekinalp \& Akkök, 2004; Karadağ, 2009; Zembat \& Yıldız, 2010) in their lives. In conclusion, since being disabled or with special needs is a long-lasting situation, it becomes inevitable for parents to live depression and hopelessness.

Nature of the psychological experiences of the parents with children with disabilities

Depression and hopelessness can be regarded as just two of various outpouring types of the difficulties of parents. Because both the reasons and the psychological results of the difficulties of parents' experiences are quite varied (Findler, Jacoby \& Gabis, 2016). For this reason, the psychological processes they experience have a distinctive characteristic (Akkök, Aşkar \& Karancl, 1992). One of the prominent features of this characteristics is the problems the parents' experiences are directly or indirectly interrelated to one another. (Tint \& Weiss, 2016). For example, a parent with depressive symptoms is most probably deprived of social support. Similarly, a parent who couldn't complete the process of acceptance of his or her child might probably withdraw into her/himself or isolate from society. Another characteristic feature is that even if they display same behavioral symptoms, the possible underlying reason for the behavior parents display might be different (Barak-Levy \& Atzaba-Poria, 2013; lacolinoa, Pellerone, Pacea, Ramacia \& Castorinaa, 2016; Schneider, 2016). For example, while a parent considers the problematic behaviors of her child as trouble for fear that she might be excluded from the society, another parent might consider these behaviors as trouble since she doesn't accept such a child. In short, problems the parents with handicapped children might be varied, and these problems are substantially interrelated. From this framework, in order to help parents cope with the problems they experience, initially, identification of the problems parents experience through a holistic perspective, and a comprehensive/eclectic intervention type can be said to be necessary.

Comprehensive/eclectic interventions in psychological counseling

Comprehensive interventions are among the most preferred approaches. Although it is not totally possible to combine some basic identifications in the same therapeutic environment within the conceptualization framework of various theories (Oddli, Nissen-Lie, \& Halvorsen, 2016), the assumption of the difficulties the individuals live are multidimensional and thus a theory might not be sufficient in terms of providing solutions for the problems of individuals causes the acceptance of comprehensive interventions (Cardoso, 2016; Hicks, Alexander, and Jones, 2016; Lin, 2016; $\mathrm{Wu}$, Huang, Jackson, Suve \& Morrow, 2016). For example, the eclectic approach that can be conducted on having parents accept their disabled child facilitates a person both benefiting from notions of psychodynamic approaches to understand personal dynamics of 
the difficulty s/he experiences and behavioristic techniques by having him or her participate in social environments to face this problem. Even though a counselor who adopts eclectic approach grounds his approach on psychoanalytic theory as in this example, s/he benefits from the techniques of behavioristic theory as well (Lin, 2016). Comprehensive approaches avoid both limiting the problems of an individual to a specific area and to a single theoretical approach (Corey, 1996; Hicks, Alexander, \& Jones, 2016). Thus, they can help counselors fulfill the needs of their clients (Hicks, Alexander, \& Jones, 2016; Lin, 2016). Considering the fact that the difficulties the parents of children with special needs are all interrelated and in a wide range, eclectic approach can be said to be a relatively functional intervention type. However, there are limited number of eclectic/comprehensive intervention studies focusing on parents of children with special needs.

Some studies were conducted with families within the framework of some theoretical approaches. In order to help parents of autistic children understand themselves and increase their well-beings, Wagner et.al (2014) used family system approach and Haugstvedt, Graff-Iversen, Bukholm, Haugli \& Hallberg (2013) used reality therapy to develop a psychological counseling program with a group, and they focused on the key points during the processes of parents' understanding themselves. Rentinck, Ketelaar, Jongmans \& Gorter (2007) focused on the adaptation processes of parents with children with cerebral palsy and tried to find out factors that affected the adaptation of parents. Whittingham, Sanders, McKinlay, \& Boyd, (2016) integrated family therapy and acceptance therapy to increase adaptation levels of parents with children with cerebral palsy and benefitted from the techniques of both approaches, and revealed the effectiveness of this approach. Cin \& Kılıç (2012) developed a group guidance program to decrease anxiety levels of parents; Şanlı \& Çelik (2015) adapted Cin \& Kılıç's (2012) program and developed a group counseling program to increase optimism levels of parents with disabled children and stated that the program was effective on mentioned variables.
As it can be seen, in most of the studies the researchers focused on some specific experiences such as parents' adaptation level, wellbeing, anxiety levels, and optimism, and the benefited from some specific theoretical approaches to fulfill these aims and it can be seen that they were successful regarding their aims. Nonetheless, the abovementioned studies were both limited to just one or a few challenging psychological experiences of parents and to specific theoretical approaches to cope with these experiences compared to present study.

This study aims to state the effectiveness of eclectic-oriented group counseling to find out psychological difficulties the parents of children with various disability types aged between $0^{-} 6$ have through a holistic perspective within the light of the opinions of parents (from a phenomenological point of view), and to cope with these difficulties. The study was conducted in two steps. The problems the parents face were set through their own perspectives in the first step; and in the second step, the group counseling program that was developed by considering all the problems stated by parents without being limited to a specific theoretical approach was applied and the effectiveness of the program on depression and hopelessness levels of parents was tested through an experimental design of $2 \times 2$ with experimental and control groups.

\section{Method}

\section{Participants}

First step of this study was conducted with $\mathbf{2 4}$ parents' demographic features of whom are given in Table 1. As for the group counseling application with the group, it was conducted with eight volunteer parents six of whom were mothers; one father and one grandmother. On the other hand, seven mothers from the same group constituted the control group of the study. Five of the participants in the experimental group were parents of children with autism, and three were parents of children with Down syndrome. As to the control group, it comprised of parents three of whom had autistic children; two had mentally retarded children; one had a hearing-impaired child; and one had a child with developmental delay. 
Table 1.

Participants

\begin{tabular}{|c|c|c|c|c|c|c|}
\hline Participant & Relationship & $\begin{array}{l}\text { Age of } \\
\text { Parent }\end{array}$ & Profession & $\begin{array}{c}\text { Maintenance } \\
\text { Time }\end{array}$ & Disability & $\begin{array}{l}\text { Age } \\
\text { of } \\
\text { Child }\end{array}$ \\
\hline${ }^{1} \mathrm{P}_{1}$ & Mother & 47 & Housewife & Continious & Autism & 4 \\
\hline${ }^{1} \mathrm{P} 2$ & Mother & 24 & Housewife & Continious & Autism & 4 \\
\hline${ }^{1} \mathrm{P}_{3}$ & Mother & 33 & $\begin{array}{l}\text { Laboratory } \\
\text { assistant }\end{array}$ & Continious & Autism & 6 \\
\hline${ }^{1} \mathrm{P} 4$ & Mother & 28 & Housewife & Continious & $\begin{array}{c}\text { Down } \\
\text { syndrome }\end{array}$ & 4 \\
\hline${ }^{1} \mathrm{P}_{5}$ & Mother & 29 & Technician & Day care & Autism & 5 \\
\hline${ }^{1} \mathrm{P} 6$ & Grandmother & 62 & $\begin{array}{l}\text { Retired } \\
\text { teacher }\end{array}$ & Continious & $\begin{array}{l}\text { Down } \\
\text { syndrome }\end{array}$ & 4 \\
\hline${ }^{1} \mathrm{P} 7$ & Father & 42 & $\begin{array}{l}\text { Shop- } \\
\text { keeper }\end{array}$ & Continious & $\begin{array}{c}\text { Down } \\
\text { syndrome }\end{array}$ & 6 \\
\hline${ }^{1} \mathrm{P} 8$ & Mother & 38 & Officer & Continious & Autism & 6 \\
\hline${ }^{2} \mathrm{Pg}$ & Mother & 33 & Solicitor & Continious & Autism & 4 \\
\hline${ }^{2} \mathrm{P} 10$ & Mother & 41 & Housewife & Continious & Autism & 5 \\
\hline${ }^{2} P_{11}$ & Mother & 30 & Housewife & Continious & $\begin{array}{l}\text { Hearing- } \\
\text { impaired }\end{array}$ & 6 \\
\hline${ }^{2} \mathrm{P} 12$ & Mother & 40 & Housewife & Continious & $\begin{array}{c}\text { Developmental } \\
\text { delayed }\end{array}$ & 5 \\
\hline${ }^{2} \mathrm{P} 13$ & Mother & 42 & Housewife & Continious & $\begin{array}{l}\text { Mental } \\
\text { retardation }\end{array}$ & 6 \\
\hline${ }^{2} \mathrm{P} 14$ & Mother & 41 & Housewife & Continious & Autism & 6 \\
\hline${ }^{2} \mathrm{P} 15$ & Mother & 51 & Housewife & Continious & $\begin{array}{l}\text { Mental } \\
\text { retardation }\end{array}$ & 7 \\
\hline P16 & Mother & 41 & Housewife & Continious & $\begin{array}{l}\text { Mental } \\
\text { retardation }\end{array}$ & 4 \\
\hline P17 & Mother & 34 & Officer & Day care & $\begin{array}{c}\text { Down } \\
\text { syndrome }\end{array}$ & 3 \\
\hline P18 & Mother & 33 & Chemist & Continious & Autism & 6 \\
\hline P19 & Nurse & 58 & $\begin{array}{l}\text { Retired } \\
\text { officer }\end{array}$ & Day care & $\begin{array}{c}\text { Down } \\
\text { syndrome }\end{array}$ & 4 \\
\hline P20 & Mother & 38 & Teacher & Continious & $\begin{array}{c}\text { Down } \\
\text { syndrome }\end{array}$ & 2 \\
\hline P21 & Mother & 47 & $\begin{array}{l}\text { Retired } \\
\text { officer }\end{array}$ & Continious & $\begin{array}{c}\text { Specific learning } \\
\text { difficulties }\end{array}$ & 7 \\
\hline P22 & Mother & 35 & Housewife & Continious & Autism & 5 \\
\hline P23 & Grandfather & 54 & Housewife & Continious & $\begin{array}{l}\text { Down } \\
\text { syndrome }\end{array}$ & 4 \\
\hline P24 & Mother & 32 & Teacher & Continious & $\begin{array}{c}\text { Down } \\
\text { syndrome }\end{array}$ & 4 \\
\hline
\end{tabular}

${ }^{1}$ Experiment group ${ }^{2}$ Control group

\section{Data Collection Tools}

The study was conducted in two different steps, and different data collection tools were used for each step. Structured interview forms (SIF) were used in the first step; and Beck Depression Inventory (BDI), Beck Hopelessness Scale (BHS) and Social Validity Survey
(SVS) that was developed by the researcher was used in the second step.

Structured Interview Form (SIF): An interview form that was developed by the researcher was used in the first step of the study. There were two open ended questions aiming at finding out the difficulties parents faced, and 
demographic questions for finding out the age, occupation, affinity to the child with disability, age of the child and type of the disability in the form.

Beck Depression Inventory (BDI): $\mathrm{BDI}$ is a scale with 21 items developed to measure the severity of depressive symptoms. Each item has a score between 0 and 3 in the scale, and the total scores that could be taken from the scale is between 0 and 63 . The scale was adapted to Turkish by Hisli (1989), and its reliability was measured to be .80 Cronbach alpha, and splithalf reliability was $\mathbf{0 . 7 4}$. It had $\mathbf{. 9 0}$ for clinical group, and .89 for normal population in terms of internal consistency values in the study conducted by Kapçı, Uslu, Türkçapar \& Karaoğlan (2008). Moreover, test-retest reliability of the scale was calculated as .94 .

Beck Hopelessness Scale (BHS): It was originally developed by Beck, Weissman, Lester \& Trexler (1974). It is a 20-item scale aimed to measure hopelessness levels of individuals for future. Validity and reliability calculations of the Turkish version of the scale was done by Seber (1991) and Durak (1993). Durak (1993) calculated internal consistency value as .85 Cronbach- $\alpha$; and item-total correlations were found between .31 and .67. Participants are asked to read each item in the scale and tick the "true" choice if the item is true for them, and tick "false" if it is false for them. If the participant ticks "true" for 11 of the items and "false" for nine of them, he or she is given a score, and the higher the score, the higher hopelessness level (Seber, 1991; Seber, Dilbaz, Kaptanoğlu \& Tekin, 1993). Scale consists of three sub dimensions which are feelings related to future, motivation loss and future expectations (Seber, 1991). Since it was presupposed that the difficulties the parents with disabled children had were mostly interrelated to each other and they caused depression in general, not the sub dimensions but total score of the scale was taken into consideration.

Social Validity Survey (SVS): Social Validity Survey was developed to evaluate whether the group counseling program that was implemented during the second step of the study was effective and met the goals or not from the first hand opinions of the participants. The scale consisted of 13 items each of which was prepared in parallel with the program content and goals. Participants were asked to read each item in the scale and give scores between 1 and 5 in which 1 referred to "I totally disagree" and 5 "I totally agree". " 1 " meant that the participant had weak attainment for the related item whereas " 5 " meant that s/he had the highest level of attainment.

\section{Procedure}

First step of the study was designed as a qualitative research, and within the light of the data gathered from the first step, a group counseling program was developed. As for the second step of the study, a $2 \times 2$ experimental design was used and the effect of the program developed during the first step on depression and hopelessness levels of parents with children with disabilities was tested. The proceedings of the study in both steps are described respectively below.

Step 1: Analysis of qualitative data and development of group counseling program (Engelli Çocuk Ebeveynleri İçin Grupla Psikolojik Danışma Programı-EÇEP):

The first step of the study was designed and conducted as a qualitative research. One of the referred ways to find out problems of the target population is conducting face to face or written interviews (Ekiz, 2009; Miles \& Huberman, 1994; Patton, 2014; Yıldırım \& Şimşek, 2005). Considering this, in order to find out the difficulties parents had due to having a disabled child, through a structured interview form including the following two open ended questions, parents were asked to state their opinions, and the written documents were analyzed through content analysis method. The questions were;

"What can you say about the psychological difficulties you lived related to the condition of your child? What kind of a help would you need about this problem? Please state in detail."

"Is there any temporary stressful situation you experience nowadays or constant one in your home? Please define in detail." 
Regarding the themes, sub themes and their contents that were found out through analyses, problem areas of parents were identified and an interaction based group counseling program that would last eight sessions was developed for the parents. The program was conducted with the same group leader in the same place for eight weeks. The program that is called Group Counseling Program with Parents with Disabled Children (Engelli Çocuk Ebeveynleri Için Grupla Psikolojik Danışma Programı-EÇEP) is semi structured and based on interaction. Both the points that should be taken into account carefully while applying EÇEP and brief description of each one of the eight sessions are listed in the following.

Implementation of EÇEP and main principles

- EÇEP is a semi-structured, interaction and eclectic approach based program. Since this approach facilitates users benefit from various theoretical bases and different techniques (Petrocelli, 2002), interactions and experiences were identified through the principles of various theoretical approaches. For example, therapeutic conditions of humanistic approach (Hayes, 2016; Patel, 2016) were provided within the framework of some basic principles such as unconditional regard and acceptance, empathy and transparency. Depending on the content of the theme of each session, different theoretical approaches were used dominantly. However, the application and techniques of Adlerian (Akdoğan, 2012), cognitive (Kennerley, Kirk\& Westbrook, 2016), realistic (Capuzzi \& Stauffer, 2016) and family system approach (Corey, 1996) were all benefitted almost in all sessions.

- As the program is semi-structured, various factors such as needs and intellectual levels of the members in group, level of the problem related to having a disabled child, resemblance of one's problem to another, and being open to change were all taken into consideration during the group process. At this point, various activities that would be useful for all members were used.

- The program in general, especially during the further sessions, focuses on subjective psychological processes of individuals. For this reason, the group leader made some preparations about the individual lives of parents regarding the data gathered from qualitative analyses and a detailed literature review was conducted prior to the process.

- Even though the main theme of each session was different, as the lives of the parents were interrelated to one another, the sessions were not limited to a single theme with regards to the experiences/sharing of the members. Sessions were usually proceeded on the basis of the sharing of the parents.

- The leader had roles for increasing the interaction among the members; make connection between the sharing of members; summarizing; providing confrontation and reflection during the sessions. Each session was started with short explanations related to the main theme of the session.

- During the group counseling, the leader and the members sat in the shape of a circle considering the equality principle of humanistic approach, and interaction was provided through spontaneous utterances without settling any order for speaking turns. Particularly the silent members were encouraged to speak.

\section{Content of EÇEP sessions}

Session 1 (meeting, setting group rules, and general results of living with a disabled child): In addition to participants' meeting one another and setting group roles, this session focused on general problems that were identified from the analyses. Interactions were provided on general difficulties regarding health problems and education needs of the disabled children of the participants, group leader asked participants to introduce themselves focusing on their distinct characteristics, and later, continued the session asking, "what do you do as parents with a disabled child?".

Session II (social isolation and relationships with social environment): Relationship of parents with society and the problems they encountered within this context were focused in this session. Especially, experiences related to social exclusion such as not being wanted at school, being regarded as strange and stigma, and their psychological consequences were shared. Considering this aim, the leader asked participants to state their experiences briefly as parents of disabled children from the social aspect and had participants interact among each other based on system approach in 
terms of the experienced obstacles. The beliefs lying behind the faced obstacles, the possible effects of individual behavior and attitudes of parents on the system as a whole were focused.

Session III (being overburdened and problems with spouse): It was found out from the analyses as a sub theme that parents of disabled children were in excessively overburdening conditions, and they always had to deal with their children and could not allocate time for themselves and their spouses, and because of this spouses occasionally had some conflicts between each other. This session focused on sharing about such problems. With respect to the aim of the session, "Whose power to what extent?" application was conducted. This implementation was developed as a parallel understanding to the one implemented by Realistic Therapy to cope with problematic situations. During this implementation, group members were asked to carry five balls which were big enough not to carry with one hand to a place in a very short period of five seconds, and the reason why it was impossible was discussed in group. Moreover, the group members were encouraged to share the things they couldn't tell to their spouses in real life. This was a parallel application to confrontation identification of Gestalt Therapy.

Session IV (anxiety regarding to the future of the child): It was found out in analyses that parents with disabled children primarily worried on what would happen to the child in future; who would look after him/her; and whether s/he would stand on his/her own feet or not. Their worries on such issues and their potential results were shared during this session. Members were asked to write what would anxiety-based problems be and bring them to the session in the previous one. Then, what the reason for these anxieties would be or what kind of underlying faulty beliefs would be about these anxieties were discussed on the basis of Cognitive Therapy.

Session $V$ (acceptance): One of the most significant findings of this study was parents' not being able to totally accept their children with disabilities despite the long time they had these children. This session focused on sharing of feelings of the parents and their ideas that fed these feelings in this context. The attitudes of a parent who totally accepted his/her child as s/he is and a parent who partially accepted his/her child, and who did the parents felt themselves closer among these two types of parents were shared. Discussions on what should be done to accept the child as s/he is were conducted.

Session VI (Psychological symptoms): Anxiety, hopelessness, depression, inhibition and somatic complaints that appeared as sub themes were focused in this session. Moreover, psychological and medical support that was necessary for parents to feel better was dwelled on as well. Both alternative medical interventions regarding the severity of psychological symptoms the parents had and the things that could be done to overcome these symptoms were discussed with parents in this session. The function of complaints was handled in the framework of Adlerian Approach, and as for their dysfunctionality it was examined considering the principles of Cognitive Therapy.

Session VII (realism): It was found out from the analyses that he parents had unrealistic expectations and irrational beliefs about their children. Particularly these problems appeared in connection with acceptance process were identified to have negative effects on functionality of parents. Within this context, realistic expectations and disappointments were focused in this session, and how parents should set realistic goals and what should be done to achieve these goals were discussed as well. An implementation called "the things that might really happen with their children and vice versa" was conducted. Since the parents in the group knew one another and the children, each parent discussed on how much realistic was the expectation written by another parent about his/her child. This was an implementation conducted in the framework of Realistic Therapy.

Session VIII (ending): Future expectations, plans and predictions of the parents were focused in this session. They were encouraged to develop realistic expectations. Moreover, the issues they did not talk about till that moment but wanted to talk were handled. Posttest and social validity scale was applied to the participants at the end of the session. 


\section{Step II: Experimental design and procedure} Second step of the study was conducted with two groups which were experimental and control group. EÇEP was applied to experimental group as independent variable; and change in hopelessness and depression levels of parents was considered as dependent variable which was examined with the comparisons made between the scores of pretest and posttest that are explained in detail in the following. Participants in control group were not included in any implementation (since it would be ethically suitable, this group was also taken to an eight-week group counseling program following the principles of EÇEP program through eclectic approach independent from the study). Since the study based on the averages of two scores of two groups it was conducted as a $2 \times 2$ experimental study. Thus, the following operations were proceeded respectively.

- All of the 24 participants were applied BDI and BHS prior to experiment and the data received were used as pretest data.

- 15 volunteers who got higher scores from both scales in pretest measurements were included in experiment process. These participants were concurrently the ones who were suitable in terms of time and other conditions to participate in the study during the implementation of the experimental part of the study. The rest nine participants were not suitable for the study at that time. Participants who were included in experimental group are shown as " $p$ " in Table 1 , and the ones who were included in control group are shown as "2 $\mathrm{P}$ ".

- Participants were randomly divided into two groups with 8 members in one group and 7 in the other. Then, the averages of their BDI and BHS scores (pretest scores) were compared and the average scores had no significant difference was identified (Table 2). One of the groups was designated as experimental group and the other as control group randomly.

- Group program was only applied to experimental group; no intervention nor study was conducted with control group during the experiment.

- Both groups were applied BDI and BHS at the end of the experiment and the average scores (posttest scores) were compared. In addition, experimental group was applied SVS at the end of the experiment.

- In order to avoid ethical violation, control group was taken into the same implementation as well at the end of the experiment.

- Each session of the program lasted approximately two hours.

Considering the experimental procedure, answers for the following hypotheses, (a) BDI and BHS posttest average scores will be significantly lower than the pretest average scores, (b) BDI and BHS posttest average scores and pretest average scores of the participants in control group will not have a significant difference, and (c) BDI and BHS posttest scores of experimental group will be significantly lower than the average posttest scores of control group were sought.

\section{Analysis of quantitative data}

This study was conducted with 15 parents 8 of whom were in experimental group and 7 in control group. This number is relatively low for the application of the parametric tests statistically. In addition, results of Levene test and variance and covariance matrix (Box's $M=$ $32,58 ; \mathrm{p}<.05)$ showed that the data did not meet the assumptions of normality; for this reason, the analyses of the data was made using nonparametric tests (Baştürk, 2010; Büyüköztürk, 2010; Uçar, 2006). Thus, in order to compare the levels of BDI and BHS scores of experimental and control groups prior to and after the experiment, Wilcoxon signed rank test, a nonparametric test, was used. As to the comparison of pretest and posttest scores of the groups, another nonparametric test, Mann Whitney $U$ test was used.

\section{Findings}

This study aimed to reveal psychological difficulties the parents of disabled children had within the light of their views through a holistic perspective and show the effectiveness of group counseling based on eclectic approach in terms of coping with these difficulties. Qualitative findings of the study that were gathered through qualitative data analyses and then findings gathered from quantitative data are shown respectively below.

Findings received from the structured interviews 
First aim of this study was to find out the psychological difficulties the parents of disabled children experienced through a holistic perspective from their opinions. With regards to this aim, data received from SIF were examined through qualitative analysis method. As a result of the analyses, parents were identified to have general and personal problems depending on having a disabled child, and these two areas were identified as main themes. General problems are the ones that appear while meeting health and education needs of the handicapped child (...as the health problems of my child appeared, I did not care of my child's having Down syndrome, which became less serious, anymore; ....; my child receives education from five different institutions...; ...my husband worries about how to meet the education costs of our son.....). Parents experience social prejudices (...her primary teacher's not accepting and excluding my daughter had affected her and me a lot ...); they face insufficient education conditions and search for new educational and social supports to cope with these problems (...we have been living in Eskişehir for almost four months for the education of my child. We are trying to get used to living in another city, another house and so on ...) during the process of meeting these needs.

As for the problems that were under the main theme of personal problems, some of them were the behavioral and adaptive problems that directly appeared during the interaction process with the child (...my daughter's failure in her lessons in my biggest problem...; ...we have problems with my child's school, lessons and behaviors ...). Some of the personal problems of the parents, on the other hand, referred to inner reasons caused by having a child with disabilities. Within the framework of this theme, (a) parents seemed not to have completed the acceptance process yet $(\ldots l$ haven't got rid of why in me yet...); (b) their children's being disabled covered almost all of their lives (... even all of our conversations are about $K$ actually. If he is happy, we are happy...; (c) parents had problems with their spouses and neighborhood (... but I think my husband is a little bit selfish... we occasionally have arguments and quarrels because of this... ...; ...l want to go somewhere nobody knows me...; I am explaining the condition of my child but the people opposite to me don't understand me and they look down on me); (d) parents showed various psychological symptoms such as unhappiness (...future is not that much bright for us...), anxiety (...thinking his future, I am worried, what will happen in the future?...), somatic complaints (...l am stressed due to him ...; ...it triggers my diabetes...; my psychology is affected ...; ...l am overstressed...) and depression special problems (...his condition caused a deep psychological devastation us...; ...thinking his future, I become more pessimistic...); (e) parents might have unrealistic expectations about their children (...l usually believe that $E$ will become normal. Even I have an expectation that he will be with us when we reach at old age).

\section{Findings received from experimental imple- mentation}

Second main aim of this study was to examine the effect of EÇEP which was developed in the framework of eclectic approach based on the opinions of the parents on depression and hopelessness levels of participants. Considering this aim, BDI and BHS average scores of participants before and after the experiment were compared both in the group and between the groups. Wilcoxon signed ranks test was used for in-group comparisons, and the findings are shown in Table 2.

As it can be seen in Table 2, there was a significant difference between the pretest and posttest BDI scores of experimental group $(z=$ $-2,52 ; p=.01)$. Considering rank means and rank sums of the differential scores, the observed difference could be in countenance of negative ranks, namely, posttest scores. These findings indicated that depression levels of the participants in experimental group decreased after the implementation of the experiment.

As for BHS scores, it can be understood from Table 2 that there was a significant difference between BHS pretest and posttest scores of experimental groups $(z=-2,5 ; p=$ $.01)$. With regards to the rank means and rank sums of the differential scores, the observed difference was in countenance of 
Table 2.

The results of Wilcoxon Signed-Rank Test

\begin{tabular}{|c|c|c|c|c|c|c|c|c|c|c|c|}
\hline \multirow[t]{2}{*}{ Groups } & \multicolumn{6}{|c|}{$\mathrm{BDI}$} & \multicolumn{5}{|c|}{$\mathrm{BHS}$} \\
\hline & & $\mathrm{n}$ & $\begin{array}{c}\text { mean } \\
\text { rank }\end{array}$ & $\begin{array}{l}\text { sum } \\
\text { rank }\end{array}$ & $\mathrm{z}$ & $p$ & $\mathrm{n}$ & $\begin{array}{c}\text { mean } \\
\text { rank }\end{array}$ & $\begin{array}{l}\text { sum } \\
\text { rank }\end{array}$ & $\mathrm{z}$ & $p$ \\
\hline \multirow{4}{*}{ Experimenta } & Negative & 8 & 4,5 & 36 & & & 8 & 4,5 & 36 & & \\
\hline & Positive & 0 & 0 & 0 & $-2,52^{*}$ & $0,01^{*}$ & 0 & 0 & 0 & $-2,53$ & $0,01^{*}$ \\
\hline & Equal & 0 & 0 & 0 & & & 0 & 0 & 0 & & \\
\hline & Negative & 4 & 2,6 & 10,5 & & & 3 & 3,5 & 10,5 & & \\
\hline \multirow[t]{2}{*}{ Controla } & Positive & 1 & 4,5 & 4,5 &,$- 81^{* *}$ & $0,41^{* *}$ & 2 & 2,25 & 4,50 & $-0,42$ & $0,42^{* *}$ \\
\hline & Equal & 0 & - & - & & & 2 & - & - & & \\
\hline
\end{tabular}

aPretest-postest comparisons were made according to positive ranks. ${ }^{*} p=.01{ }^{* *} p>.05$

negative ranks, that is, posttest scores. In other words, hopelessness level scores of participants in experimental group decreased at the end of experiment. These findings verified the first hypothesis of the study. On the other hand, both BDI $(z=-, 81 ; p>.05)$ and BHS $(z=-$ ,42; $p>$.05) pretest-posttest compar isons of control group did not have any significant difference. This showed that the second hypothesis of the study was also verified. Mann-Whitney $U$ test was applied to compare pretest and posttest scores of the groups after the experiment, and the results are shown in Table 3.

Table 3.

The results of Mann-Whitney $U$ Test

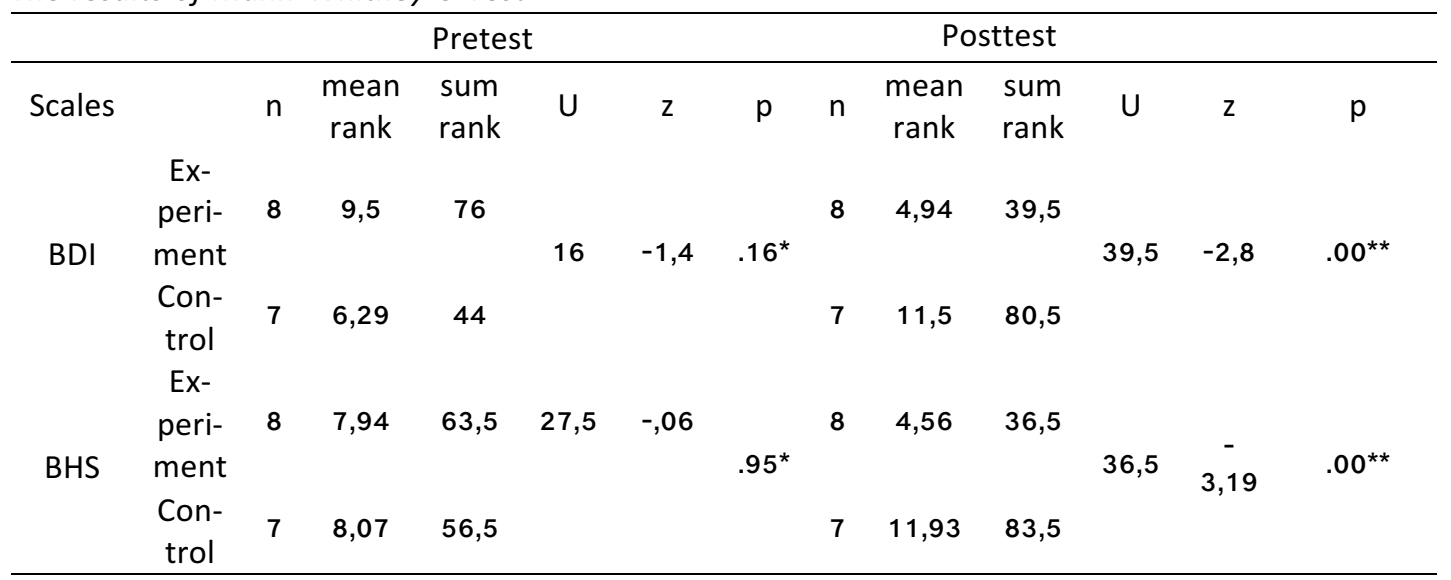

${ }^{*} p>.05{ }^{* *} p<.01$

As it can be seen from the data shown in Table 3, both experimental and control groups did not have any significant difference in terms of BDI and BHS scores prior to the experiment. However, posttest BDI scores of experimental group and control group $(U=39,5$; $p<.01$ ), and posttest BHS scores of both experimental and control groups $(U=36,5 ; p<.01)$ revealed significant differences. With regards to the rank means, both BDI and BHS posttest scores of experimental groups were significantly lower than those of control group. This meant that depression and hopelessness scores of the participants in experimental group decreased significantly compared to the scores of the control group after the experiment. This showed that third hypothesis of the study was verified as well.

Opinions of participants on EÇEP was evaluated through SVS and frequencies of their reactions are shown in Table 4. Studying on frequency and percentage values in Table 4 , it can be seen that a great majority of the participants in experimental group chose "I 
agree" or "I totally agree" choices for almost all of the items in the scale. On the other hand, it can also be seen that the answers to "I am neutral" choice were at noticeable level for some items. One participant answered $2^{\text {nd }}$ and $3^{\text {rd }}$ items as "I totally disagree" but nobody chose "I disagree" choice for any of the items. Considering the data gathered from social validity scale, it can be understood that the participants in experimental group had a high level of satisfaction in terms of joining group counseling process. Almost all of the participants stated a high level of satisfaction for almost all of the 13 items in the scale.

Table 4.

Responses of participants in experimental group to the items in Social Validity Scale

\begin{tabular}{|c|c|c|c|c|c|}
\hline \multirow[b]{2}{*}{ Items } & \multicolumn{5}{|c|}{ Frequencies } \\
\hline & a & $\mathrm{b}$ & C & d & e \\
\hline $\begin{array}{l}\text { 1. I believe that this group application is a useful experience for me in } \\
\text { general. }\end{array}$ & & & & 3 & 5 \\
\hline $\begin{array}{l}\text { 2. My participation in the process helped me develop relationships with } \\
\text { my relatives, neighbors, friends and other people around me easier. }\end{array}$ & 1 & & 2 & 1 & 4 \\
\hline $\begin{array}{l}\text { 3. This application helped me solve the conflicts we lived with my hus- } \\
\text { band depending on disability of our child. }\end{array}$ & 1 & & 1 & 2 & 3 \\
\hline $\begin{array}{l}\text { 4. This application helped me develop healthier relationship with my both } \\
\text { disabled and healthy children. }\end{array}$ & & & & 4 & 4 \\
\hline $\begin{array}{l}\text { 5. This group work helped me make realistic detections related to the } \\
\text { condition of my child. }\end{array}$ & & & 1 & 3 & 4 \\
\hline $\begin{array}{l}\text { 6. I have changed some of my behavioral patterns that made me unhappy } \\
\text { by participating in this application. }\end{array}$ & & & 2 & 5 & 1 \\
\hline $\begin{array}{l}\text { 7. I can say that I have more realistic goals related to my child and me } \\
\text { after the program. }\end{array}$ & & & 2 & 4 & 2 \\
\hline $\begin{array}{l}\text { 8. The application helped me gain some skills to cope with difficulties } \\
\text { related to the disability of my child. }\end{array}$ & & & & 4 & 4 \\
\hline 9. I can say that I am braver against the life after the program. & & & 3 & 3 & 3 \\
\hline 10. I believe that I can reflect the things we shared in group to my real life. & & & 1 & 5 & 2 \\
\hline $\begin{array}{l}\text { 11. I believe that I will experience the effects of the awareness I gained in } \\
\text { this process for a long time in the future. }\end{array}$ & & & 1 & 2 & 5 \\
\hline $\begin{array}{l}\text { 12. This application helped me develop positive feelings compared to the } \\
\text { past. }\end{array}$ & & & 1 & 2 & 5 \\
\hline $\begin{array}{l}\text { 13. I recommend such an application to the ones who have similar prob- } \\
\text { lems with me. }\end{array}$ & & & & 2 & 6 \\
\hline
\end{tabular}

a; I strongly disagree, b; I disagree, c; I am neutral, d; I agree, e; I strongly agree

\section{Discussion}

As the first step of this study, the problems of the participants were identified from their perspectives. And then, EÇEP that was developed in accordance with these problems was applied, and the effectiveness of the program on depression and hopelessness levels of parents was examined.

During the first step of the study, parents were identified to have a wide range of problems that were same with the ones stated in related literature (Ayyıldız, Şener, Kulakçı \& Veren, 2012; Bridge, 2005; Cocks, 2000;
Özşenol et.al., 2003). Findings also showed that the problems of the parents were interrelated to each other. For example, the psychological symptoms such as hopelessness, helplessness, physical complaints displayed by the families were related to social exclusion (...her primary teacher's not accepting and excluding my daughter had affected her and me a lot ...) at one side and allocating a great deal of time to the disabled child (...l am always on the go, I am always getting too much tired...) or spouse relationships (... but I think my husband is a little bit selfish... he expects everything from me... we occasionally have 
arguments and quarrels because of this...) on the other side, and each one of all these factors were understood to have effects on others. On the other hand, although the problems parents experienced were varied, they usually end up with depression and hopelessness for them (...l want to go somewhere nobody knows me...; future is not that much bright for us. And I cannot think it will be bright ...; ...thinking his future, I am worried...). These findings imply that depression and hopelessness have been a part of the lives of the parents with children with disabilities. Thus, being disabled is not a temporary condition; it might last long or forever (Conk \& Yıldırım, 2005).

The quantitative data gathered from the second step of the study revealed that group counseling process based on eclectic approach to decrease depression and hopelessness levels of parents with disabled children was functional. The most significant reason for this can be the implementation process's not being limited to a specific theoretical approach nor to a specific problem area. For example, while questioning technique of Adlerian approach was used for investigating the dynamics and functions of somatic complaints of group members and for having members gain insights (Dreikurs, 1997), behavioral exposure therapy (Abramowitz, Deacon \& Whiteside, 2012) was directly used to help parents cope with negative perspectives towards themselves in the upcoming sessions of the implementation. Findings of this eclectic and comprehensive study were similar to the ones that had been conducted using similar methods. For example, Wagner et.al, (2014) conducted a study within the scope of family system approach, and focused on family in the context of the pattern it is in rather than the family itself alone, and stated that such an approach eased families understand themselves and it had positive contributions to the wellbeing levels of families. On the other hand, Whittingham et.al. (2016) integrated family therapy and acceptance therapy instead of applying a single theoretical approach in order to increase life quality and adjustment levels of parents, and found out that this approach was effective.

The program's appearing to be effective after the experimental study was significantly related to the process and content of group formation process as well. Principally, while structuring the group process, a holistic approach was adopted deriving from the hypothesis that problems of parents were interrelated to one another. Within this framework, not only the symptoms of parents regarding their depression and hopelessness, but also all the information and needs they stated in structured interview forms were benefitted. Thus, quantitative data of the study showed that in addition to depression and hopelessness, parents experienced somatic complaints, problems with spouses and social environment, social prejudices, educational problems, overburden and acceptance problems, and the program was developed and implemented considering all these symptoms. All of the themes gathered from qualitative data were mentioned directly or indirectly in almost all sessions. On the other hand, in order to use these themes functionally, the researcher was not just content with the qualitative data gathered from the present study, and he examined the other scientific studies related to these concepts in literature (Bahar et.al., 2009; Beckett, 2009; Bitsika \& Sharpley, 2004; Blacher et.al., 2016; Ceylan \& Aral, 2007a,b; Ergüner-Tekinalp \& Akkök, 2004; Foster, Garber \& Durlak, 2008; Karadağ, 2009; Zembat \& Yıldız, 2010; Zibricky, 2014) and integrated them in experimental implementation.

Program was found out to be effective in decreasing depression and hopelessness levels of experimental group, and this showed that holistic approach was felicitous for parents with disabled children to cope with depression and hopelessness. For this reason, an important finding of the study was the fact that it showed the interconnection among the problems the parents of disabled children experienced. For example, while studying on the problems parents had with their spouses, their economic problems and reasons for these problems were focused on as well. From this perspective, although the theme was the problems with spouses, the other variables that were related to this was also taken into consideration. Since the problems of parents with disabled children were interrelated to each other, these problems were handled together. 
The finding of the problems of parents' being interrelated to one another was compatible with the information given in literature. Montes \& Halterman (2008) stated that since the care of a disabled child would be more difficult and long lasting compared to a normal child, it required parents provide home care for their child, and this situation would cause parents lose their jobs. Participant parents of this study stated that they were in an overburden due to having a disabled child, and they had economic problems to provide suitable education facilities for their children. Moreover, some of them stated that they had to move another city, and this caused problems between spouses. Parallel with these findings, it was stated in literature that having a disabled child would affect all of the family functions (Cuzzocrea, Larcan \& Westh, 2013; Özşenol et.al., 2003). In other respects, although group implementation was not directly or solely focused on how to cope with depression and hopelessness, its being effective on these variables made it possible to think that depression and hopelessness experiences of parents with disabled children had distinct characteristics. Akkök, Aşkar \& Karancı (1992) stated that parents of disabled children had distinct characteristics which corresponded with these findings of this study.

In addition to the experimental implementation, the effectiveness of EÇEP was evaluated through SVS as well. Going through the SVS scores that was prepared to take subjective opinions of parents on EÇEP applied on them, it could be seen that participants stated positive reactions to a great majority of the items in the scale. In other words, most of the participants in experimental group replied as "I agree" or "I strongly agree" for the items that were related to the effectiveness of the program. Only one parent stated that the program did not provide contributions for them just for the $2^{\text {nd }}$ and $3^{\text {rd }}$ items in the scale.

Considering the fact that the contents of the items in the scale were written parallel with EÇEP goals, program can be said to have achieved its goals. On the other hand, as most of the reactions were positive, the program can also be said that it was considered applicable from the perspectives of parents. Considering the results of the scale as a whole, it could be implied that group work provided parents to benefit from the group; helped them set more functional relationships with their spouses, other children and social environments; supported them accept their children with his or her disability; supported them to set more realistic goals for both themselves and their children; and helped them overcome the psychological symptoms they experienced. For instance, all of the participants stated in the $13^{\text {th }}$ item of the scale that they recommended such a program to the individuals who had similar problems with theirs.

EÇEP's having significant contributions for parents to overcome depression and hopelessness was related to program's being directly structured in accordance with the opinions and needs of the parents. Thus, none of the themes the parents did not refer to in SIF were proceeded; instead, the themes that were stated as problems by the participants were taken into consideration. Having worked with a program that was constituted from the experiences of parents showed that this study directly focused on the problems of parents. From this perspective, the program could be said to be solution-oriented.

\section{Conclusion}

Findings of this study showed that the psychological support that should be provided for parents of disabled children should be comprehensive, interrelated, focusing on genuine problems of individuals, and solution-oriented. As for the quantitative findings that showed that both depression and hopelessness levels of parents decreased after the experimental implementation compared to control group, they can be the evidence for the effectiveness of solution-oriented and comprehensive approaches.

\section{Limitations and further research}

This study was designed as a $2 \times 2$ experimental study and it did not include a follow-up study. For this reason, how would depression and hopelessness levels of participants change in long term after the implementation was not clarified. Moreover, since there wasn't a placebo group in the study, the depression and hopelessness levels of the participants might have been stemmed from the group process 
itself as well. For this reason, conducting the same study by including both a placebo group and conducting follow-up measures might provide more reliable results. Eclectic approach's having been found effective on decreasing depression and hopelessness levels of parents in this study showed that this approach can be used more commonly in the field. The approach that was used in this study required working without being limited to a specific theory and problem. This might cause relative uncertainties in terms of the identification of the implementation of goals or limitations of activities in the process. For this reason, limiting the number of theories with a specific number such as three or four and integrating them into the implementation might be facilitator in terms of identifying therapeutic goals and activities for the implementations that would be conducted through eclectic approach.

\section{References}

Abramowitz, J. S., Deacon, B. J., \& Whiteside, S. P. (2012). Exposure therapy for anxiety: Principles and practice. Guilford Press.

Akandere, M., Acar, M., \& Başbuğ, G. (2009). Zihinsel ve fiziksel engelli çocuğa sahip anne ve babaların yaşam doyumu ve umutsuzluk düzeylerinin incelenmesi. Selçuk Üniversitesi Sosyal Bilimler Enstitüsü Dergisi, 22, 23-32.

Akbulut, S. (2012). Gerçekten eşit miyiz? Acı (ma), zayıf gör (me) ve yok say (ma) ekseninde engelli ayrımcılığı. K. Çayır \& M. A Ceyhan (der.), Ayrımcılık: Çok Boyutlu Yaklaşımlar, İstanbul: Istanbul Bilgi Üniversitesi Yayınları.

Akkök, F., Aşkar, P., \& Karancı, N. (1992). Özürlü bir çocuğa sahip anne-babalardaki stresin yordanması. Özel Eğitim Dergisi, 1(2), 8-12.

Algood, C. L. \& Harris, C. (2013). Parenting success and challenges for families of children with disabilities: An ecological systems analysis. Journal of Human Behavior in the Social Environment, 23, 126-136.

Al-Kandari, H. Y. \& Al-Qashan, H. (2010). Maternal self-efficacy of mothers of children with intellectual developmental disabilities, down syndrome, and autism in Kuwait. Child Adolescence and Social Work Journal, 27, 21-39.
Ardıç, A. (2013). Otistik spektrum bozukluğu tanısı almış çocukların ailelerine yönelik bir psiko-eğitsel grup programının ebeveynlerin bazı psikolojik değişkenleri üzerindeki etkisi (Yayınlanmamış doktora tezi). Anadolu Üniversitesi, Eğitim Bilimleri Enstitüsü, Eskişehir.

Ardıç, A. (2010). Özel gereksinimli çocuk ve aile. A. Cavkaytar (Ed). Özel Eğitimde Aile Eğitimi ve Rehberliği. Ankara: Maya Akademi.

Ayyıldız, T., Şener, D. K., Kulakçı, H., \& Veren, F. (2012). Zihinsel engelli çocuğa sahip annelerin stresle baş etme yöntemlerinin değerlendirilmesi. Ankara Sağlık Hizmetleri Dergisi, 11(2), 1-12.

Bahar, A., Bahar, G., Savaş, H. A., \& Parlar, S. (2009). Engelli çocukların annelerinin depresyon ve anksiyete düzeyleri ile stresle basa çıkma tarzlarının belirlenmesi. Fırat Sağlık Hizmetleri Dergisi, 4(11), 97112.

Barak-Levy, Y. \& Atzaba-Poria, N. A. (2013). Paternal versus maternal coping styles with child diagnosis of developmental delay. Research in Developmental Disabilities, 34(6), 2040-2046.

Baştürk, R. (2010). Bütün yönleriyle SPSS örnekli nonparametrik istatistiksel yöntemler. Ankara: Anı Yayıncılık.

Beck, A.T., Weissman, A., Lester, D., \& Trexler, L. (1974). The measurement of pessimism: The Hopelessness Scale. Journal of Consulting and Clinical Psychology, 42(6), 861865.

Beckett, A.E. (2009) Challenging disabling attitudes, building an inclusive society: Considering the role of education in encouraging non-disabled children to develop positive attitudes towards disabled people. British Journal of Sociology of Education, 30(3), 317-329.

Bitsika, V. ve Sharpley, C. (2004). Stress, anxiety and depression among parents of children with autism spectrum disorder. Australian Journal of Guidance ve Counselling, 14(2), 151-161.

Blacher, J., Lopez, S., Shapiro, J., \& Fusco, J. (2016). Contributions to depression in latina mothers with and without children with retardation: Implications for caregiving. Family Relations, 46(4), 325-334. 
Bridge, G. (2005). Disabled children and their families in Ukraine. Social Work in Health Care, 39(1-2); 89-105.

Büyüköztürk, Ş. (2010). Sosyal bilimler için veri analizi el kitabı: istatistik, araştırma deseni, SPSS uygulamaları ve yorum (12. ed.). Ankara: Pegem Akademi.

Capuzzi, D. \& Stauffer, M. D. (2016). ACA Counseling and Psychotherapy: Theories and Interventions. New York: John Wiley \& Sons.

Cardoso, P. (2016). Integrating Life-Design Counseling and Psychotherapy: Possibilities and Practices. The Career Development Quarterly, 64(1), 49-63.

Cavkaytar, A. (2013). Özel eğitime gereksinim duyan çocuklar ve özel eğitim. Özel eğitime gereksinimi olan öğrenciler ve özel eğitim (7. Basım), İ. H. Diken (Ed.) içinde (s. 1-28). Ankara: Pegem Akademi.

Cavkaytar, A. (1998). Zihin engellilere özbakım ve ev içi becerilerinin öğretiminde bir aile eğitim programının etkililiği (Yayınlanmamış doktora tezi). Anadolu Üniversitesi Sosyal Bilimler Enstütüsü, Eskişehir.

Cavkaytar, A., Ardıç, A., Sönmez, M., Özdemir, O., \& Olcay, S. (2013). Çevrimiçi aile bilgi ve destek eğitim programı (E-ABDEP). http://e-abdep.anadolu.edu.tr/. 24 Şubat 2016.

Ceylan, R. \& Aral, N. (2007a). An examination of the correlation between depression and hopelessness levels in mothers of disabled children. Social Behavior and Personality, 35(7), 903-908.

Ceylan, R. \& Aral, N. (2007b). Hopelessness levels of mothers with and without disabled children. Pakistan Journal of Social Sciences, 4(6), 746-750.

Cin, A. \& Kılıç, M. (2012). Özürlü çocuğu olan anne babaların kaygı düzeylerini azaltmaya yönelik bir grup rehberliği uygulaması. Deneysel olarak sınanmış grupla psikolojik danışma ve rehberlik programları II, S. Erkan \& A. Kaya (Eds.). (s. 70-102). Ankara: Pegem Akademi.

Cocks, A. (2000). Respite care for disabled children: Micro and macro reflections, Disability ve Society, 15(3), 507-519.

Conk, Z. \& Yıldırım, F. (2005). Zihinsel yetersizliği olan çocuğa sahip anne/babaların stresle başa çıkma tarzlarına ve depresyon düzeylerine planlı eğitimin etkisi. Cumhuriyet Üniversitesi Hemşirelik Yüksek Okulu Dergisi, 9(2), 1-10.

Corey, G. (1996). Theory and Practice of counseling and psychotherapy (5th ed.). Pasific Grove California: Brooks/cole Publishing Company.

Coşkun, Y. \& Akkaş, G. (2009). Engelli çocuğu olan annelerin sürekli kaygı düzeyleri ile sosyal destek algıları arasındaki ilişki. Ahi Evran Üniversitesi Kırşehir Eğitim Fakültesi Dergisi (KEFAD), 10(1), 213-227.

Cuzzocrea, F., Larcan, R., \& Westh, F. (2013) Family and parental functioning in parents of disabled children, Nordic Psychology, 65(3), 271-287.

DePauw, K. P. (2000). Social-cultural context of disability: Implications for scientific ınquiry and professional preparation. Quest, 52(4), 358-368.

Durak, A. (1993). Beck umutsuzluk ölçeği'nin geçerliği üzerine bir çalışma Nayınlanmış yüksek lisans tezi). Ankara Üniversitesi, Sosyal Bilimler Enstitüsü, Ankara.

Ekiz, D. (2009). Bilimsel araştırma yöntemleri (2. Basım). Ankara: Anı Yayıncılık.

Ergüner-Tekinalp, B. \& Akkök, F. (2004). The effects of a coping skills training program on the coping skills, hopelessness, and stress levels of mothers of children with autism. International Journal for the Advancement of Counselling, 26(3), 257-269.

Eripek, S. (2005). Özel eğitim. Eskişehir, Anadolu Üniversitesi AÖF yayınları.

Findler, L., Jacoby, A. K., \& Gabis, L. (2016). Subjective happiness among mothers of children with disabilities: The role of stress, attachment, guilt and social support. Research in Developmental Disabilities, 55, 44-54.

Fish, W. W. (2008). The IEP meeting: Perceptions of parents of students who receive special education services, preventing school failure. Alternative Education for Children and Youth, 53(1), 8-14.

Foster, C. E. J., Garber, J., \& Durlak, J. A. (2008). Current and past maternal depression, maternal interaction behaviors, and children's externalizing and internalizing symptoms. Journal of Abnormal Child Psychology, 36(4), 527-537. 
Glenn, S., Cunningham, C., Poole, H., Reeves, D., \& Weindling, M. (2008). Maternal parenting stress and its correlates in families with a young child with cerebral palsy. Child: Care, Health and Development, 35(1), 71-78.

Hastings, R. P. \& Brown, T. (2002). Behavior problems of children with autism, parental self-efficacy, and mental health. American Journal on Mental Retardation, 107(3), 222-232.

Haugstvedt, K. T. S., Graff-Iversen, S., Bukholm, I. R. K., Haugli, L., \& Hallberg, U. (2013). Processes of enhanced self-understanding during a counselling programme for parents of children with disabilities. Scandinavian Journal of Caring Sciences. 27, 108116.

Hayes, C. (2016). Is suffering Therapeutic? An exploration of buddhist ideas and Rogers' six conditions. Person-Centered ve Experiential Psychotherapies, 15(3), 245-255.

Hicks, R., Alexander, V., \& Jones, C. M. (2016). Counselling and psychotherapy orientations in Australia: Responses from 24 Australian psychotherapists. Psychology, 7(8), 1146-1153.

Hisli N. (1989). Beck depresyon envanterinin üniversite öğrencileri için geçerliği, güvenirliği. Türk Psikoloji Dergisi, 7, 3-13.

lacolinoa, C., Pellerone, M., Pacea, U., Ramacia, T., \& Castorinaa, V. (2016). Family functioning and disability: A study on italian parents of disabled children. Retrievew from http://dx.doi.org/10.15405/epsbs.2016.05.5

Kapçı, E.G., Uslu, R., Türkçapar, H., \& Karaoğlan, A. (2008). Beck depression inventory II: evaluation of the psychometric properties and cut-off points in a Turkish adult population. Depression and Anxiety, 25(10), 104-110.

Kennerley, H., Kirk, J., \& Westbrook, D. (2016). An Introduction to Cognitive Behaviour Therapy: Skills and Applications. London: SAGE Publication.

Lin, Y. N. (2016). The framework for integrating common and specific factors in therapy: A resolution. International Journal of Psychology and Counselling, 8(7), 81-95.

Maatta, T., Maatta, J., Tervo-Maatta, T., Taanila, A., Kaski, M., \& Livanainen, M. (2011). Healthcare and guidelines: A population-based survey of recorded medical problems and health surveillance for people with Down syndrome. Journal of Intellectual and Developmental Disability, 36(2), 118-126.

Miles, M.B. \& Huberman, A.M. (1994). Qualitative data analysis. An expanded sourcebook (2nd Ed.). London: SAGE Publication.

Montes, G. \& Halterman, J. S (2008). Child care problems and employment among families with preschool-aged children with autism in the United States. Pediatrics. 122(1), 201-208.

Oddli, H. W., Nissen-Lie, H. A., \& Halvorsen, M. S. (2016). Common therapeutic change principles as "sensitizing concepts": A key perspective in psychotherapy integration and clinical research. Journal of Psychotherapy Integration, 26(2), 160.

Özşenol, F., Işıkhan, V., Ünay, B., Aydın, H. İ., Akın, R., \& Gökçay, E. (2003). Engelli çocuğa sahip ailelerin aile işlevlerinin değerlendirilmesi. Gülhane Tıp Dergisi, 45(2), 156-164.

Patel, M. M. The Theory and rhetoric of person-centered therapy from the view of Carl Rogers. International Journal of Research and Analytical Reviews, 3(2), 58-61.

Patton, M. Q. (2014). Analiz yorum ve raporlaştırma. Nitel araştırma ve değerlendirme yöntemleri Bütün, M. \& Demir S.B. (Eds.) içinde (s. 429-539). Ankara: Pegem Akademi.

Petrocelli, J. V. (2002). Processes and stages of change: Counseling with the transtheoretical model of change. Journal of Counseling and Development, 80(1), 22-30.

Reichman, N.E., Corman, H., \& Noonan, K. (2008). Impact of child disability on the family. Maternal and Child Care Journal, 12, 679-683.

Rentinck, I. C. M., Ketelaar, M., Jongmans, M. J., \& Gorter, J. W. (2007). Parents of children with cerebral palsy: A review of factors related to the process of adaptation. Child Care Health and Development, 33(2), 161-169.

Schneider, C. (2016). Family, disability and Identity.

DOI: 10.17774/CDJ1.32016.2.20575874.

Retrieved from file:

cdj_2_disability_family_identity.pdf.

Seber, G. (1991). Beck umutsuzluk ölçeğinin geçerlik ve güvenirliği üzerine bir çalışma 
(Yayımlanmamış doçentlik tezi). Anadolu Üniversitesi, Sağıı Bilimleri Enstitüsü, Eskişehir.

Seber, G., Dilbaz, N., Kaptanoğlu, C., \& Tekin, D. (1993). Umutsuzluk ölçeği: geçerlilik ve güvenirlilik. Kriz Dergisi, 1(3), 139-142

Shanker, A. (1995). Full inclusion: Is neither free nor appropriate. Educational Leadership, 52(4), 18-21.

Spann, S.J, Kohler, F.W., \& Soenksen, D. (2003). Examining parents' Involvement in and perceptions of special education services: An Interview with families in a parent support group. Focus on Autism and Other Developmental Disabilities, 18(4), 228-237.

Spender, Q., Stein, A., Dennis, J., Reilly, S., Percy, E., \& Cave, D. (1996). An exploration of feeding difficulties in children with Down syndrome. Developmental Medicine ve Child Neurology, 38(8), 681-694.

Şanlı, E., \& Çelik, S. B. (2015). Grup rehberliğinin engelli çocuk sahibi annelerin iyimserlik düzeyini artırmaya etkisi. Uluslararası Sosyal Araştırmalar Dergisi, 8(41), 841-849.

www.sosyalarastirmalar.com ISSN: 13079581 adresinden alınmıştır.

Tint, A. \& Weiss, J. A. (2016). Family wellbeing of individuals with autism spectrum disorder: A scoping review. Autism, 20(3), 262275.

Uçar, N.Ş. (2006). Parametrik olmayan (nonparametric) hipotez testleri. SPSS uygulamalı çok değişkenli istatistik teknikleri, Ş. Kalaycı (Ed.). içinde (s. 83-112). Ankara: Asil Yayın Dağıtım.

Uygur, R., Özen, O. A., Baş, O., Gönül, Y., \& Songur, A. (2013). Hemiplejik serebral palsili çocukların üst ekstremitelerinin sağlam tarafı da gelişim geriliği gösterir. Genel Tıp Dergisi, 23(2), 33-8.

Wagner, D.V., Borduin, C. M., Kanne, S., Mazurek, M. O., Farmer, J. E., \& Brown, R. A. (2014). Multisystemic therapy for disruptive behavior problems in youths with autism spectrum disorders: a progress report. Journal of Marital and Family Therapy, 4O(3), 319-331.

Witcher, A.E. (1987). The Process of grief as experienced by parents of children with handicaps. ERIC Database. ED 320369.
http://files.eric.ed.gov/fulltext/ED320369.p df. Accessed 10 Jan 2016.

Yıldırım, A. \& Şimşek, H. (2011). Sosyal bilimlerde nitel araştırma yöntemleri (8th ed.). Ankara: Seçkin Yayınları.

Whittingham, K., Sanders, M. R., McKinlay, L., \& Boyd, R. N. (2016). Parenting Intervention Combined with Acceptance and Commitment Therapy: A Trial with Families of ChildrenwWith Cerebral Palsy. Journal of Pediatric Psychology, 41(5), 531-542.

Wu, B., Huang, X., Jackson, T., Su, D., \& Morrow, S. L. (2016). Counselors' Current Counseling Practice a Qualitative Investigation in China. The Counseling Psychologist, 44(3), 306-330.

Zembat, R. \& Yıldız, D. (2010). A comparison of acceptance and hopelessness levels of disabled preschool children's mothers. Procedia-Social and Behavioral Sciences, 2(2), $1457^{-} 1461$.

Zibricky, C. D. (2014). New knowledge about motherhood: An autoethnography on raising a disabled child. Journal of Family Studies, 20(1), 39-47. 